\title{
Synchronisation in vivo: Temporary inhibition of DNA synthesis in the rat embryo with hydroxyurea
}

M. F. RAJEWSKY, E. FABRICIUS and D. F. HỦLSER, Abteilung Physikalische Biologie, MaxPlanck-Institut für Virusforschung, 74 Tübingen, BRD

\section{Summary}

As part of experimental studies on the synchronisation of mammalian cell populations in vivo, the proliferative response of rat embryo cells (18th day of gestation) was investigated following transplacental administration of hydroxyurea (HU). DNA synthesis was strongly inhibited by i.p. injection of a single dose of 0.25 or $0.5 \mathrm{mg} \mathrm{HU} / \mathrm{g}$ body weight, for periods of 2.5 and $4.5 \mathrm{~h}$, respectively. Reversal of blocks occurred rapidly due to the short half-life $(45 \mathrm{~min})$ of the inhibitor in the embryo. The resulting synchronizing effects were analysed in terms of mitotic indices and rate of ${ }^{3} \mathrm{H}-\mathrm{Td} \mathbf{R}$ incorporation for a period of $18 \mathrm{~h}$ after administration of $\mathrm{HU}$.

In preceding publications [8, 9] we have reported results of experiments on the in vivo synchronisation of proliferating rat tumor cells by temporary inhibition of DNA synthesis with hydroxyurea (HU). These studies have been further elaborated $[3,10]$ and extended to a number of normal cell systems. The following communication is concerned with the response of the proliferating cells of the rat embryo to the transplacental administration of $\mathrm{HU}$.

\section{Materials and Methods}

BD IX rats [1] on the 18th day of gestation were used. HU (Nutritional Biochemicals Corp., Cleveland, Ohio) was administered intraperitoneally in pyrogen-free, sterile physiological saline, and the concentration of 
the inhibitor in embryos and maternal blood determined as a function of time after injection, using a colorimetric procedure modified after Nery [5] and Philips et al. [6] and described elsewhere $[2,3] .{ }^{3} \mathrm{H}$ Methyl-thymidine $\left({ }^{3} \mathrm{H}-\mathrm{TdR}\right.$; Radiochemical Centre, Amersham, UK.; spec. act. $17.5 \mathrm{Ci} / \mathrm{mM}$; 0.2 or $3.0 \mu \mathrm{Ci} / \mathrm{g}$ body weight) was injected i.p. at different times after a $\mathrm{HU}$ pulse and the animals sacrificed 30 min later. The embryos were fixed in a 20 -fold volume of ethanol-acetic acid $(3: 1)$ at $4^{\circ} \mathrm{C}$. After two changes at $48 \mathrm{~h}$ intervals they were either embedded in Paraplast (Shandon Scientific Co.), sectioned at $4 \mu \mathrm{m}$, Feulgen-stained, and dipped in Ilford K5 nuclear emulsion for autoradiographic analysis, or dried to constant weight at $40^{\circ} \mathrm{C}$ in a vacuum desiccator. In the latter case, the ${ }^{3} \mathrm{H}$-activity per mg dry weight was determined in a liquid scintillation spectrometer (Nuclear Chicago Corp.) after combustion of the specimens according to a modified dry oxidation procedure (see [7]). In some experiments the ${ }^{3} \mathrm{H}$ activity of standard size deparaffinized sections (medial longitudinal sections of the embryos) mounted on millipore filters (Millipore Filter $\mathrm{GmbH}$ ) was measured by liquid scintillation spectrometry, after two 5 min extractions with cold $5 \%$ trichloroacetic acid (TCA). The fetal liver (all cell types) served as a representative tissue for the determination of the fraction of cells in mitosis. $\geqslant 3500$ cells per sample were counted in Feulgen-stained sections. The mean mitotic index in untreated controls was $2.97 \% \pm 0.65$ (S.D.).

\section{Results and Discussion}

As demonstrated in fig. 1, DNA synthesis in the fetal rat is strongly inhibited by $\mathrm{HU}$ (curves $B$ and $C$ ). According to curve $B$ the incorporation of ${ }^{3} \mathrm{II}-\mathrm{TdR} 1 \mathrm{~h}$ after a pulse dose of $0.25 \mathrm{mg} \mathrm{HU} / \mathrm{g}$ body weight is reduced to about $7 \%$ of control. However, counts of filter mounted sections where acid soluble material was more completely removed by extraction with cold TCA, gave a value of $1.8 \% \pm 0.5$ (S.D.) at this time point. Comparative autoradiographic grain count analyses, showed that this residual ${ }^{3} \mathrm{H}$-activity was not due to a small fraction of cells with unimpaired DNA synthesis, but rather to a persisting low rate of ${ }^{3} \mathrm{H}-\mathrm{TdR}$ incorporation by all cells blocked in the $S$ period of their cell cycle.

Previous studies in adult rats $[3,8,9,10]$ have shown that inhibition of DNA synthesis in normal and malignant tissues is reversed when the tissue concentration of $\mathrm{HU}$ falls

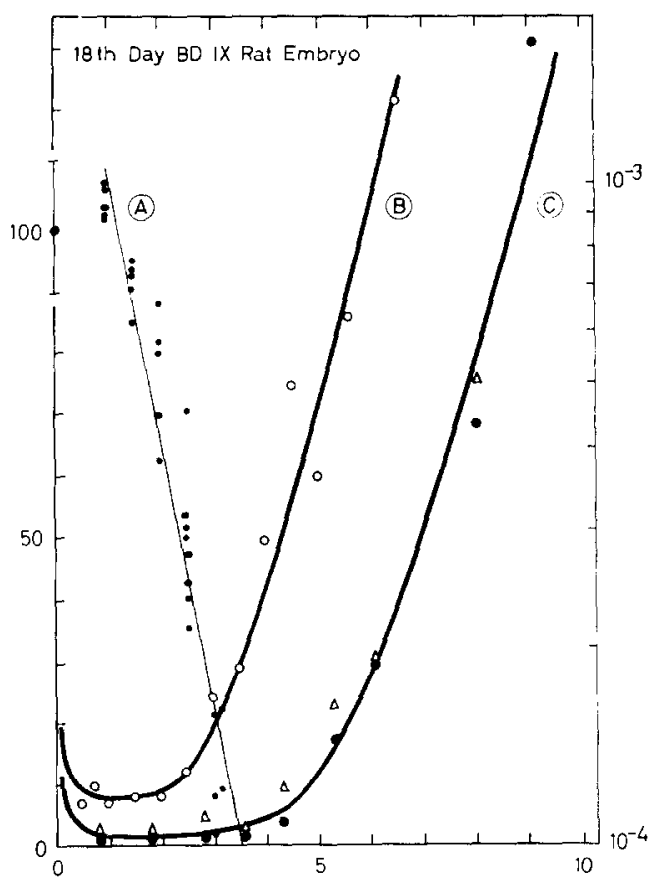

Fig. 1. Abscissa: time after HU pulse (hours); ordinate: (left) ${ }^{3} \mathrm{H}$-activity/mg dry weight $(\mathrm{O}, \bullet) ;{ }^{9} \mathrm{H}$-activity/ section $(\triangle) ;(r i g h t) \mathrm{HU}$ concentration $\left(\right.$ moles $\left./ 10^{3} \mathrm{~g}\right)$.

${ }^{3} \mathrm{H}-\mathrm{TdR}$ incorporation into $\mathrm{BD}$ IX rat embryos as a function of time after pulse doses of $0.25(\mathrm{O}$; curve $B$ ) and $0.5 \mathrm{mg} \mathrm{HU} / \mathrm{g}$ body weight $(\bullet, \triangle$; curve $C$ ), respectively. Each point represents the mean value for 2-8 embryos. Standard deviation of control given on left ordinate.

Curve A: HU concentration in BD IX rat embryos as a function of time after administration of $\mathbf{0 . 2 5}$ mg HU/g body weight. Each point represents one embryo. Slope calculated by regression analysis.

below a critical range of $1-3 \times 10^{-5}$ moles $/ 10^{3}$ $\mathrm{g}$, and that reversion occurs almost without delay, due to the short half-life $\left(\mathrm{t}_{\frac{1}{2}}\right)$ of the inhibitor in blood and tissues. Curve $A$ in fig. 1 demonstrates the exponential decrease of $\mathrm{HU}$ concentration in the embryo after a dose of $0.25 \mathrm{mg} \mathrm{HU} / \mathrm{g}$ body weight. In contrast to the value found for maternal blood $(20 \mathrm{~min}), \mathrm{t}_{\frac{1}{2}}$ in the embryo was 45 min. This difference may be due to the complex exchange mechanisms between the fetal and maternal circulatory system. Surprisingly, however, the slower decrease of HU concentration in the embryo did not 
lead to a corresponding prolongation of inhibition of fetal DNA synthesis. Instead, the observed block durations equalled the values measured in proliferating tissues of the adult animal $[9,10]$, i.e. the times required for the HU concentration to decrease to the $10^{-5}$ moles $/ 10^{3} \mathrm{~g}$ level with a $t_{1}$ of $20-30$ $\min [2,3]$. There is at present no obvious explanation for this finding except that it seems to indicate a lower sensitivity of fetal cells versus adult cells with respect to the inhibitory effect of HU. However, the possibility is still under discussion (sec [11]) that inhibition of DNA synthesis may not be effected by HU itself but by an unknown metabolite formed from $\mathrm{HU}$ itself but by an unknown metabolite formed from $\mathrm{HU}$ in the cell. In the latter case, a lower sensitivity of fetal cells towards the inhibitory action of HU could be the expression of a reduced capacity for its metabolic "activation".

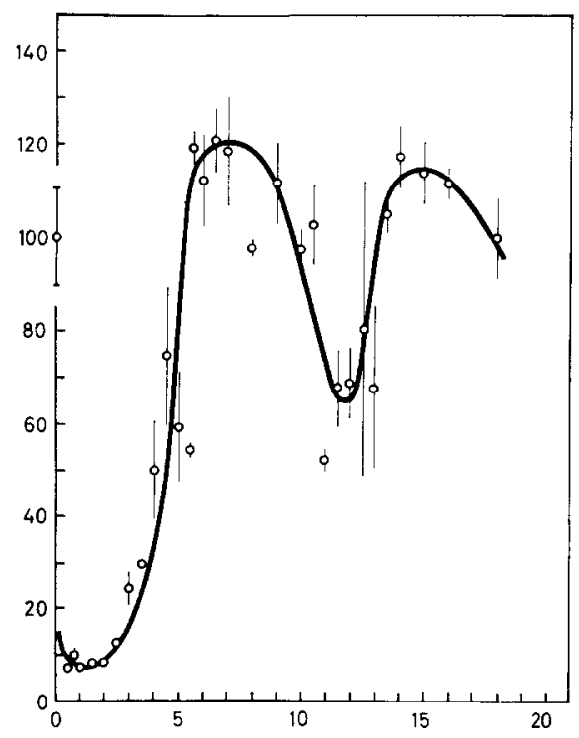

Fig. 2. Abscissa: time after HU pulse (hours); ordinate: ${ }^{3} \mathrm{H}$-activity/mg dry weight ( $\%$ of control).

${ }^{3} \mathrm{H}-\mathrm{TdR}$ incorporation into BD IX rat embryos as a function of time after a pulse dose of $0.25 \mathrm{mg}$ $\mathrm{HU} / \mathrm{g}$ body weight. Each point represents the mean value for 3-8 embryos. Standard deviation of control given on the ordinate.

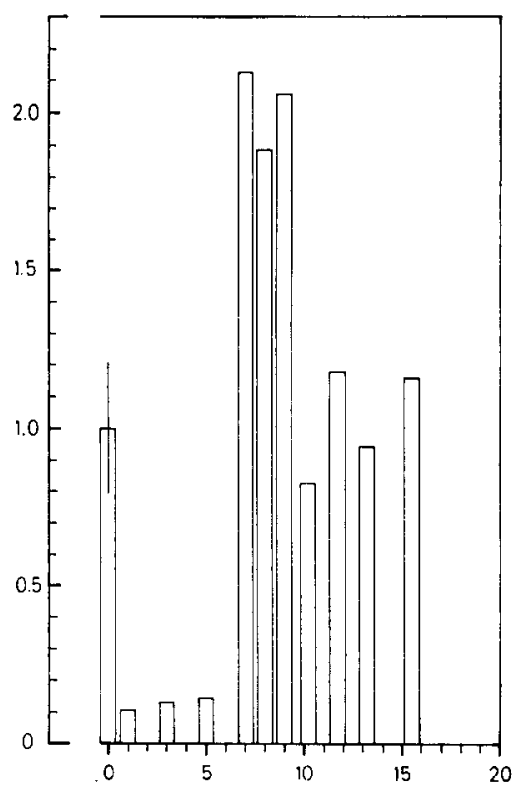

Fig. 3. Abscissa: time after HU pulse (hours); ordinate: fraction of cells in mitosis (relative units).

Fraction of mitotic cells in the liver of BD IX rat embryos as a function of time after a pulse dose of $0.25 \mathrm{mg} \mathrm{HU} / \mathrm{g}$ body weight. Standard deviation of control given as vertical bar.

In subsequent experiments, the rate of ${ }^{3} \mathrm{H}-\mathrm{Tdr}$ incorporation into the rat embryo (fig. 2), and the fraction of mitotic cells in the fetal liver (fig. 3) were determined as a function of time for up to $18 \mathrm{~h}$ after a pulse dose of $0.25 \mathrm{mg} \mathrm{HU} / \mathrm{g}$ body weight. The data show, that after a block period of about $2.5 \mathrm{~h}$ there is a peak of DNA synthesis at about $7 \mathrm{~h}$, followed by a maximum of the mitotic index at $7-9 \mathrm{~h}$. Due to the spread of experimental points, a precise timing of the maxima and minima of DNA synthesis, after the first post-block peak of ${ }^{3} \mathrm{H}-\mathrm{TdR}$ incorporation is no longer possible. However, the data suggest the presence of a minimum at 11-12 $\mathrm{h}$, followed by a second maximum at about $15 \mathrm{~h}$. Assuming that the rate of ${ }^{3} \mathrm{H}-\mathrm{TdR}$ incorporation essentially represents the number of cells synthesizing DNA at a given time, the curve could be 
interpreted to mean that the average postblock duration of $(\mathrm{G} 2+\mathrm{M}+\mathrm{G} 1)$ was $8-9 \mathrm{~h}$. This period corresponds to the time elapsed between the termination of the block and the onset of the second maximum of DNA synthesis. Considering the rise of the mitotic peak at about $6 \mathrm{~h}, \mathrm{t}_{\mathrm{G} 2}$ was probably of the order of $2-3 \mathrm{~h}$. This value is in fair agreement with data obtained for 7 different cell types of the rat embryo on the 20th day of gestation [4]. Similar to previous observations in a malignant cell system of the rat $[8,9]$, the sharp rise and the height of the mitotic peak at 7-9 h suggest that after reversal of an HU block, cells which had been blocked in $\mathrm{S}$ may complete DNA synthesis faster than under normal conditions. This, in turn, would explain a temporary increase in the rate of cells entering mitosis. Possible molecular mechanisms underlying this effect on DNA synthesis have been discussed [9].

The present data indicate that temporary inhibition of DNA synthesis and partial synchronisation of proliferating cells in the embryo can be achieved by transplacental administration of HU. No toxic effects on the embryos were recorded after a dose of $0.25 \mathrm{mg} \mathrm{HU} / \mathrm{g}$ body weight in terms of survival, weight at birth, and mortality after birth. The incidence of malignant tumors in the offspring was not increased (period of observa- tion: 20 months; 35 animals). After administration of $0.5 \mathrm{mg} \mathrm{HU} / \mathrm{g}$ body weight, the mortality of the litter slightly exceeded the control range, mainly due to disturbancies of lactation in the mothers. It remains to be shown whether, and to what degree, inhibition of DNA synthesis by $\mathrm{HU}$ in different cell populations of the embryo is accompanied by killing of cells in $\mathrm{S}$, as observed in other mammalian cell systems (see $[6,9]$ ).

The authors are indebted to I. Arndt, O. Beck, and H. Rajewsky for expert technical assistance. This investigation was supported by the Deutsche Forschungsgemeinschaft.

\section{REFERENCES}

1. Druckrey, H, Danneberg, P, Dischler, W \& Steinhoff, D, Arzneimittel-Forsch 12 (1962) 911.

2. Fabricius, E, M. D. Thesis, University of Tübingen (1971).

3. Fabricius, E \& Rajewsky, M F, Europ j clin biol. res. In press.

4. Löbbecke, E A, Schultze, B \& Maurer, W, Exptl cell res 55 (1969) 176.

5. Nery, R, Analyst 91 (1966) 388.

6. Philips, F S, Stcrnberg, S S, Schwartz, H S, Cronin, A P, Södergren, J E \& Vidal, $\mathbf{P}$ M, Cancer res 27 (1967) 61 .

7. Rajewsky, M F, Boophysik 3 (1966) 65.

8. Rajewsky, M F, Abstr IInd meeting European study group for cell proliferation (ESGCP), Schloss Reisensburg, Germany (1968).

9. Rajewsky, M F, Exptl cell res 60 (1970) 269.

10. Rajewsky, M F, Hülser, D F \& Fabricius, E. Submitted for publication (1971).

11. Rosenkranz, H S, Pollak, R D \& Schmidt, R M, Cancer res 29 (1969) 209.

Received March 12, 1971 